\title{
Polybrominated diphenyl ether in the East Asian environment: A critical review
}

\author{
Yawei Wang ${ }^{a}$, Guibin Jiang ${ }^{\mathrm{a}, *}$, Paul K.S. Lam ${ }^{\mathrm{b}}$, $\mathrm{An} \mathrm{Li}^{\mathrm{c}}$ \\ ${ }^{a}$ State Key Laboratory of Environmental Chemistry and Ecotoxicology, Research Center for Eco-Environmental Sciences, \\ Chinese Academy of Sciences, P.O. Box 2871, Beijing, 100085, China \\ ${ }^{\mathrm{b}}$ Research Centre for Coastal Pollution and Conservation, Department of Biology and Chemistry, \\ City University of Hong Kong, 83 Tat Chee Avenue, Kowloon, Hong Kong \\ ${ }^{\mathrm{c}}$ School of Public Health, University of Illinois at Chicago, 2121 West Taylor Street, MC-922, Chicago, Illinois 60612-7260, United States
}

Received 13 January 2007; accepted 30 March 2007

Available online 17 July 2007

\begin{abstract}
Polybrominated diphenyl ethers (PBDEs) have been extensively used as flame retardants in consumer goods. Sufficient evidence shows that PBDEs have been rapidly accumulating in the environment worldwide. In Asia, deca-bromodiphenyl ether has been produced and used in large quantities, while penta-BDE has largely ceased in the mid-1990s. This paper summarizes and critically reviews the status of PBDE pollution in East Asia, with emphases on the comparisons with Europe and North America and the interpretation of the differences. In general, the concentrations of PBDEs in atmosphere, sludge, human and biological samples of East Asia are comparable to or lower than those in Europe and North America. However, in the sediments of waters near densely populated and heavily industrialized areas, PBDE levels are among the highest ever reported in the literature. In Japan and China, concentrations of PBDEs in sediment cores showed an increasing trend for the past 2030 years. Also, PBDEs levels in human breast milk in Japan increased about 10-fold in the past 20 years. The presence of PBDEs in fur seal has increased about 150-fold in 1994 than that in 1972. Regional and inter-continental transport cannot be confirmed due to insufficient information. However, the detection of a number of PBDE congeners in a pristine lake on the Qinghai-Tibet Plateau may be an evidence of their long-range transport.
\end{abstract}

(C) 2007 Published by Elsevier Ltd.

Keywords: Polybrominated diphenyl ethers; East Asia; Review

\section{Contents}

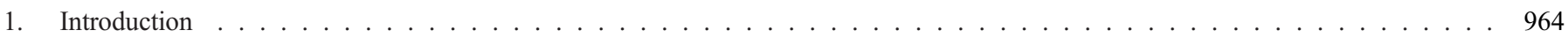

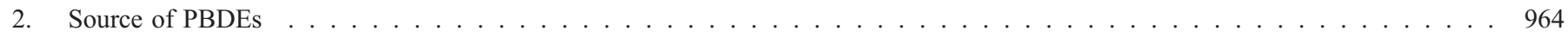

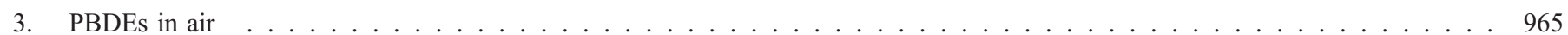

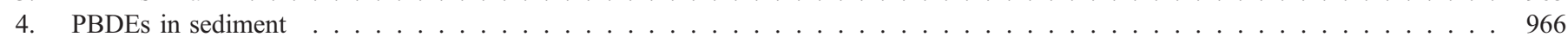

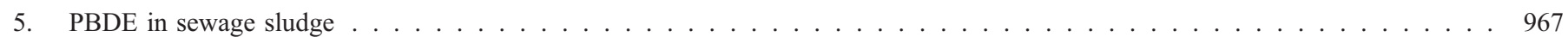

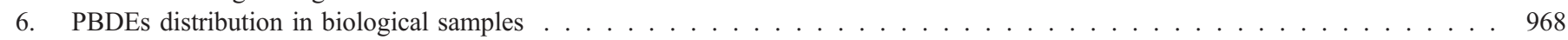

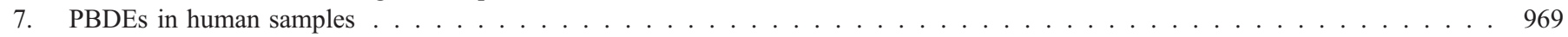

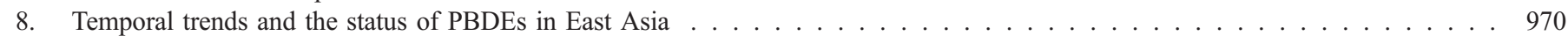

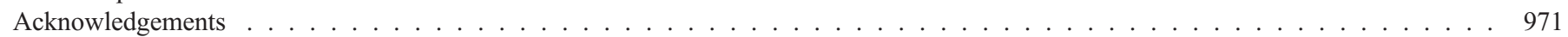

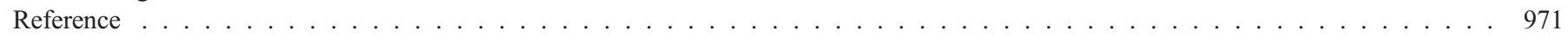

* Corresponding author. Tel.: +86106284 9179; fax: +861062849179.

E-mail address: gbjiang@rcees.ac.cn (G. Jiang). 


\section{Introduction}

Polybrominated diphenyl ethers (PBDEs) are extensively used as flame retardants (FR) in various polymers, and especially in electronic equipment such as computers and television sets (WHO, 1994). The global demand for PBDEs has increased rapidly since the 1970s. In 1992, the global production of PBDEs was about 40,000 tonnes, but in 2001 this had increased to approximately 67,000 tonnes (www.bsef.com, 2006). Commercial PBDE mixtures are produced at three degrees of bromination to give deca-BDE, which consists of 97-98\% decabromodiphenyl ether (de-BDE); octa-BDE, which consists of $10-12 \%$ hexabromodiphenyl ethers (HxBDEs), $43-$ $44 \%$ heptabromodiphenyl ethers (HpBDEs), and 31-35\% octabromodiphenyl ethers (OcBDEs); and penta-BDE, which consists of $50-62 \%$ pentabromodiphenyl ethers (PeBDEs) and 24-38\% tetrabromodiphenyl ethers (TeBDEs) (Darnerud et al., 2001).

Brominated flame retardants (BFRs) have saved lives from fire. However, they have aroused concern due to their persistence, bioaccumulation potential, and possible adverse effects on wildlife and humans. Evidence has also emerged that PBDEs may be developmental neurotoxicants, and cause neurochemical and hormonal deficiencies (Eriksson et al., 2001; Viberg et al., 2002; Zhou et al., 2002). In order to balance potential adverse effects from PBDEs due to their persistence, bioaccumulative and toxic nature, the European Union (EU) has banned all uses of penta-BDE and octa-BDE in the EU market, despite their societal benefits. Similarly, United States has ceased productions of these two BFRs in 2005.

The sheer amount of PBDEs that are emitted into the environment has created problems for the ecosystem and public health. There have been several reviews on PBDEs in North America (Hale et al., 2003) and Europe over the past years (Covaci et al., 2003; de Wit, 2002; Hites, 2004; Law et al., $2003,2006)$. In many areas, PBDEs have been detected in biotic and abiotic matrices including air, sludge, sediment, fish, birds, marine mammals, and humans and Levels of PBDEs in biota show a steady increase that parallels the historic rate of their production. The concentrations of PBDEs in Swedish human milk had been increasing during the period 1972-1997 (Norén and Meironyté, 2000). Indeed, PBDE concentrations in human blood and tissue have increased exponentially almost 100 -fold since the 1970s, doubling about every five years (Hites, 2004; Norén and Meironyté, 2000). Much work has been carried out on the analysis, physicochemical properties, toxicology, and environmental fate of PBDEs.

Asia is growing in global importance due mainly to its rapid economic development. Urbanization grows at an unprecedented pace. As a result, consumption of PBDEs as well as the production of commodities containing PBDEs, notably electronics, has increased rapidly. In addition, export of electronic waste (e-waste) in the name of "recycling" from developed counties to developing countries, especially for East and South Asia, such as China, India, and Pakistan, which is creating a potentially significant new sources of environmental PBDEs in these countries (Martin et al., 2004). However, accurate records of the consumption and import of PBDEs into Asia is lacking. Research on the spatial distribution and time trends of PBDEs in the Asian environment is limited, despite the increasing concerns from legislators, scientists, and the general public worldwide.

This paper is a critical review of the current status of PBDEs in East Asia. Most of the studies that are reviewed are from China, Japan, Hong Kong, Korea, and Singapore. Because of the scarcity of available data, transport and transformation of PBDEs were not reviewed, and comparison of the current to previous status of PBDEs is also not possible in many cases. In most papers reviewed, data are available only for congeners $28,47,99,100,153,154,183$, and 209. Special attention should be paid to the discussion of BDE-209, which is photolytically and thermally labile so that some studies may have under-reported concentrations (Söderström et al., 2002; Eriksson et al., 2004).

\section{Source of PBDEs}

In 2001, the world demand for PBDEs was about 67,000 tonnes, of which Asian demand accounted for about $40 \%$ (www.bsef.com, 2006). The Asian shares of the global market for penta-, octa- and deca-BDE products are $0 \%, 52 \%$, and $42 \%$, respectively, with 2000 tonnes of octa-BDE and 23,000 tonnes of deca-BDE in 1999 (de Wit, 2002).

Much of the Asian production of deca-BDE takes place in China, mainly in factories in the east of the country. In 2001, the production of deca-BDE was about 13,500 tonnes per annum, and consumption has continued to increase rapidly in recent years (Xia et al., 2005). The consumption of BFRs in South Korea accounts for approximately $56 \%$ of the total flame retardant market and the demand has increased by $10 \%$ per year in the last decade (Korea Environment Institute, 2001). In 2002, the consumption of deca-BDE reached 12,324 tonnes, while the demand of penta- and octa-BDEs was only about 80 tonness in South Korea (Korea Institute of Science and Technology Information, 2002). In Japan, only octa-BDE, deca-BDE and tetrabromobisphenol-A (TBBPA) are the BFRs currently in use, imported, produced and sold.

The release of PBDEs to the environment can occur during the initial synthesis, incorporation into products, the lifetime of such products, and their disposal as wastes (Danish Environmental Protection Agency, 1999). During the past decade, many developed counties export e-waste to developing countries, rather than recycling it within their own borders, and countries in East and Southeast Asia are among the major destinations. Such "recycling" activities have created a particular type of PBDE emission source (Wang et al., 2005a). China has long been suspected of receiving and disposing of the bulk of the world's dumped computers and electronic components. Martin et al. (2004) estimated that up to 261,000 tonnes of PBDEs were imported into Guangdong province in 2002 in scrap electronic devices. This estimate is about 3-5 times the global production of PBDEs in 1999. Additional information is needed for a more accurate estimation of emissions from these sources. 


\section{PBDEs in air}

At room temperature, the vapor pressure of PBDEs is very low. Nonetheless, PBDEs may be released into air from their host polymers (Sun and Zhou, 2005), especially in products in which the percentage of PBDEs is as high as $30 \%$ by weight, because PBDEs are additive rather than reactive FRs. The highest PBDE concentrations in air have been found in electronics recycling plants, where products such as computers, printers, television sets, and microwave ovens are dismantled and the plastic components shredded. Tamade et al. (2002) revealed that the concentrations of PBDEs in the TV set back cover and dust inside TV set were found to be $68,000 \mu \mathrm{g} \mathrm{g}^{-1}$ and $230 \mu \mathrm{g} \mathrm{g}^{-1}$ respectively. Other sources of PBDEs to air include solid waste incinerators, and landfills (Agrell et al., 2004; ter Schure et al., 2004a; Liu et al., 2005a).

Wania and Dugani (2003) predicted that some of the lowand intermediate-brominated congeners have long range transport potential (LRTP) comparable to those of highly chlorinated PCBs whereas highly brominated PBDE congeners are not likely to have significant LRTP. However, recent studies implied that BDE-209 also have the same potential for LRAT if sorbed to aerosol particles (Gouin et al., 2006).

Data on PBDEs in the air of East Asia are very scarce. Highvolume air samplers were unavailable in some studies, and cannot be used in remote regions where electrical power supply is not available. Table 1 gives a comparison of some investigative findings on atmospheric PBDE concentrations in East Asia.

Using passive air samplers, Jaward et al. (2005) collected 77 samples from a large area in Asia, including $32(13$ rural + 19 urban) from China, 20 (13 rural +7 urban) from Japan, 15 from South Korea, and 10 from Singapore, between September and November of 2004, to examine the levels of PCBs, other organochlorine compounds, and PBDEs. The results showed that the PBDE concentrations at most of the sampling sites were below the detection limits. The total PBDE concentration (the sum of BDEs-17, 28, 32, 47, 49, 75, 99, 100) ranged from below detection limit to $340 \mathrm{pg} \mathrm{m}^{-3}$. The most abundant congeners were BDEs-47 and 99. On the whole, PBDE concentrations in urban samples were a little higher than those from rural sites. Higher concentrations of PBDEs were measured in urban stations such as Xi'an and Guangzhou, which are the capitals of Chinese provinces. The PBDE concentrations in air in China, South Korea, Japan, and Singapore were higher than those in the open Indian Ocean (2004-2005, average value $2.5 \mathrm{pg} \mathrm{m}^{-3}$, high volume sampler) (Wurl et al., 2006), comparable to those in Europe (2002, 0.06$43 \mathrm{pg} \mathrm{m}^{-3}$, passive air sampler, 25 urban and 46 rural sites) (Jaward et al., 2004), but lower than those in southern Ontario (2000, 88-1250 $\mathrm{pg} \mathrm{m}^{-3}$, high volume sampler, rural site, BDE209 was not measured) (Gouin et al., 2002) and east-central United States (2002-2004, average value $100 \mathrm{pg} \mathrm{m}^{-3}$, high volume sampler) (Hoh and Hites, 2005).

Another study was conducted by Wang et al. (Wang et al., 2005b) from July to September 2003 to investigate the latitudinal distribution of airborne particulate PBDEs from the
Table 1

Comparison of atmospheric PBDE concentrations in East Asia and other countries

\begin{tabular}{|c|c|c|c|c|c|}
\hline Sampling site & Date & $\begin{array}{l}\text { PBDE } \\
\text { congener }\end{array}$ & $\begin{array}{l}\text { Concentration } \\
\left(\mathrm{pg} \mathrm{m}^{-3}\right)\end{array}$ & $\begin{array}{l}\text { Sampling } \\
\text { mode }\end{array}$ & References \\
\hline Far East Asia & 2003 & $\begin{array}{l}28,47, \\
66,85, \\
99,100, \\
138,153, \\
154,183, \\
209\end{array}$ & $<2.3-198.9^{\mathrm{a}}$ & $\mathrm{H}^{\mathrm{b}}$ & $\begin{array}{l}\text { Wang et al. } \\
(2005 b)\end{array}$ \\
\hline $\begin{array}{l}\text { North Pacific } \\
\text { Ocean }\end{array}$ & & & $<1.4-36.9^{\mathrm{a}}$ & & $\begin{array}{l}\text { Wang et al. } \\
(2005 b)\end{array}$ \\
\hline Arctic & & & $<2.58-60.9^{\mathrm{a}}$ & & $\begin{array}{l}\text { Wang et al. } \\
(2005 b)\end{array}$ \\
\hline $\begin{array}{l}\text { Kyoto, Japan } \\
\text { (urban) }\end{array}$ & 2000 & $\begin{array}{l}28,47, \\
49,66, \\
77,99, \\
100,153, \\
154,183, \\
209\end{array}$ & $4.5-113^{\mathrm{c}}$ & $\mathrm{H}$ & $\begin{array}{l}\text { Hayakawa } \\
\text { et al. (2004) }\end{array}$ \\
\hline $\begin{array}{l}\text { China (13 rural, } \\
19 \text { urban sites) }\end{array}$ & 2004 & $\begin{array}{l}17,28, \\
32,47, \\
49,75, \\
99,100\end{array}$ & $<0.03-67$ & $\mathrm{P}^{\mathrm{d}}$ & $\begin{array}{l}\text { Jaward et al. } \\
(2005)\end{array}$ \\
\hline Singapore & & & $2.0-6$ & & $\begin{array}{l}\text { Jaward et al. } \\
(2005)\end{array}$ \\
\hline $\begin{array}{l}\text { Japan (13 rural, } \\
7 \text { urban sites) }\end{array}$ & & & $1.0-14$ & & $\begin{array}{l}\text { Jaward et al. } \\
(2005)\end{array}$ \\
\hline South Korea & & & $0.4-5.2$ & & $\begin{array}{l}\text { Jaward et al. } \\
(2005)\end{array}$ \\
\hline
\end{tabular}

${ }^{\mathrm{a}}$ Concentrations (gas + particle phases).

${ }^{\mathrm{b}} \mathrm{H}=$ High-volume air sampler.

${ }^{\mathrm{c}}$ Concentrations (gas phase).

${ }^{\mathrm{d}} \mathrm{P}=$ Passive air sampler.

Bohai Sea to the high Arctic. A total of 49 samples were analyzed for 11 PBDE congeners (BDEs-28, 47, 66, 100, 99, $85,154,153,138,183$, and 209), and the concentrations ranged from 2.25 to $198.9 \mathrm{pg} \mathrm{m}^{-3}$ with a mean value of $58.3 \mathrm{pg} \mathrm{m}^{-3}$. These values were higher than atmospheric PBDE concentrations (BDEs-17, 28, 47, 85, 99, 100, 153, 154, 183, and 209) from England (2000-2001, 0.22-37 $\mathrm{pg} \mathrm{m}^{-3}$, high volume sampler, semirural site) (Lee et al., 2004) and in the region of the Baltic Sea (2001, 0.4-78.5 $\mathrm{pg} \mathrm{m}^{-3}$, high volume sampler, remote site) (ter Schure et al., 2004b). Wang also found that PBDE concentrations decrease with increasing latitude from the mid to high North Pacific Ocean (Wang et al., 2005b). In the city of Guangzhou in 2004, samples of air were collected to determine the levels, compositional profiles, and gas-particle distribution of PBDEs (Chen et al., 2006a). The mean atmospheric concentrations were comparable to or slightly higher than those in many other locations in the world, and BDE-209 was the most dominant congener $(>70 \%)$, with its concentrations higher than those in North America and Europe. High concentrations of BDE-209 in air samples from the Bohai Sea to the high Arctic and the region of the Baltic Sea also proved that BDE-209 has LRAT potential. This should be mentioned since BDE-209 in air can be a potential input the other environmental matrices by atmospheric deposition and can debrominated to lower brominated congeners. The 
congener profile was similar to that in Japan but different from those in North America and Europe, which was probably a result of the different PBDE formulas that are predominantly used in the two regions.

Atmospheric PBDE levels at particular sites in Japan have been assessed. In Osaka district, Japan, Ohta et al. (2002) reported in 2001 that the total amount of tri- to hepta-BDEs was $2-6.6 \mathrm{pg} \mathrm{m}^{-3}$ and deca-BDE was $100-340 \mathrm{pg} \mathrm{m}^{-3}$. Very high levels of deca-BDE were measured in particulate matter in air that was collected between 1993 and 1994 from urban areas of the city. The concentration of deca-BDE ranged from 83$3060 \mathrm{pg} \mathrm{m}^{-3}$, and the levels of tetra- to hexa-BDEs ranged from a few to several tens of $\mathrm{pg} \mathrm{m}^{-3}$ (Watanabe et al., 1995). In Kyoto, Japan, the measured atmospheric concentrations of the total of mono- to nona-BDEs were $4.5-65 \mathrm{pg} \mathrm{m}^{-3}$ and that of deca-BDE was from below limit of detection to $48 \mathrm{pg} \mathrm{m}^{-3}$ (Hayakawa et al., 2004). The authors also found that the concentrations of atmospheric PBDEs were higher in samples collected in summer than those in winter.

\section{PBDEs in sediment}

Mai et al. (2005) examined the spatial and temporal distributions of PBDEs in sediment from the Pearl River Delta and the South China Sea. In August through October 2002, they collected 66 surface sediment samples and analyzed the total concentrations of 10 PBDE congeners (BDEs-28, 47, $66,100,99,154,153,138,183$, and 209). The concentrations of the targeted PBDE congeners were mostly $<50 \mathrm{ng} \mathrm{g}^{-1}(0.04-$ $94.7 \mathrm{ng} \mathrm{g}^{-1}$, dry weight) for the nine tri- through hepta-BDEs, and ranged from 0.4 to $7340 \mathrm{ng} \mathrm{g}^{-1}$, dry weight, for BDE-209. Composition analysis showed that the main congener was BDE-
209 , which accounted for $72.6-99.7 \%$ of the total concentration of all of the targeted congeners. The major source of PBDEs was thought to be waste discharge from cities. Zheng et al. (2004) collected surface sediments from coastal locations in the Pearl River estuary and analyzed them for 12 PBDE congeners (BDEs-3, 15, 28, 47, 60, 85, 99, 100, 138, 153, 154, and 183). The total PBDE concentrations in the sediment samples ranged from 0.15 to $13.03 \mathrm{ng} \mathrm{g}^{-1}$ (dry weight). The highest PBDE concentrations were at the sites of major shipping/offloading facilities, with enclosed harbor. The contamination levels reported from the two studies are in rank order agreement.

Liu et al. reported the concentration of PBDEs in 13 sediment samples that were taken from Hong Kong marine waters (Liu et al., 2005b). The highest $\Sigma_{15}$ PBDE concentrations of $53.6 \mathrm{ng} \mathrm{g}^{-1}$ dry weight was found around the most heavily populated areas of Victoria Harbour and Sai Kung and the lowest concentration of $1.7 \mathrm{ng} \mathrm{g}^{-1}$ dry weight was found in a relatively remote location. The authors noticed that the concentrations of PBDEs in sediment in Hong Kong are higher than in other areas, but the concentration of BDE-209 was only $2.92 \mathrm{ng} \mathrm{g}^{-1}$ dry weight, far lower than the level at other locations. This site is near the coastal region of Macao, which has received PBDEs discharged from Pearl River Delta (Chen et al., 2005). Hong Kong harbor, where highest PBDE concentrations in sediment were recorded, is near the presumed source (such as manufacturing bases for electronic and electrical products) (Mai et al., 2005). A pollutant distribution pattern from Hong Kong to Macao may result in a concentration gradient in the sediments.

A comparison of PBDE levels in sediment in East Asia is given in Table 2, which indicates that PBDE concentrations in sediment in specific areas such as Pearl River Delta and rivers

Table 2

PBDE concentrations in sediment in different parts of the world (ng $\mathrm{g}^{-1}$, dry weight)

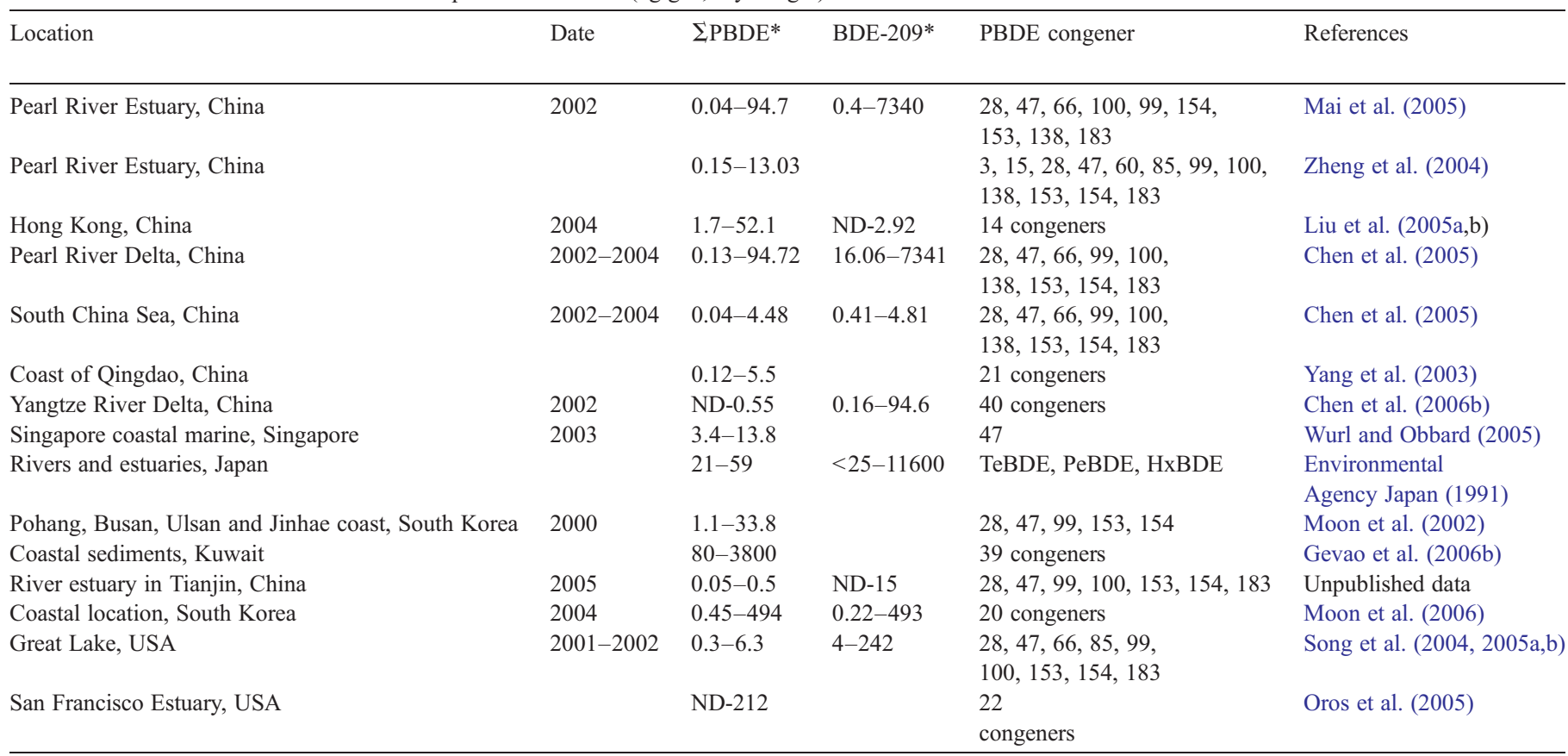

$* \mathrm{ND}=$ below detection limit. 


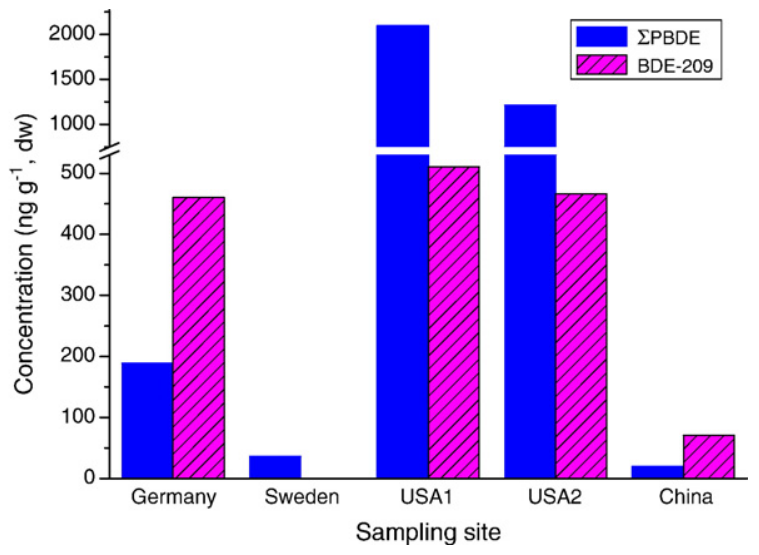

Fig. 1. Mean concentration of PBDEs (ng $\mathrm{g}^{-1}, \mathrm{dw}$ ) in sewage sludge from different countries. Germany (Knoth et al., 2004); Sweden (wet weight) (Öberg et al., 2002); USA1: Lake Superior watershed communities (Hale et al., 2003); USA2: Michigan watershed communities (Hale et al., 2003); China: (Wang et al., 2007).

and estuaries in Japan are higher than those in many other near urban water bodies, such as the San Francisco Bay in the United States (Table 2) and the harbors of Almeria and Tarragona of Spain in Europe (Netherlands, 2001, 14-22 ng g $\mathrm{g}^{-1}$ for $\Sigma_{9}$ PBDE and 240-1650 $\mathrm{ng} \mathrm{g}^{-1}$ for BDE-209, respectively; Spain, 2003, 0.16-3.94 $\mathrm{ng} \mathrm{g}^{-1}$ for $\Sigma_{11}$ PBDE and 2.46-132 $\mathrm{ng}$ $\mathrm{g}^{-1}$ for BDE-209, respectively) (Verslycke et al., 2005; Eljarrat et al., 2005). But at sampling sites outside the "hot spots" areas, the sediment concentrations of PBDEs reported from Asia seemed comparable or lower than those in the other countries.

\section{PBDE in sewage sludge}

A huge amount of the components of consumer goods, such as residues of polyurethane foam from upholstered furniture, can enter sewers after they are discarded and fragmented (Hale et al., 2002). Sewage sludge is considered one of the most pollutant-rich environmental matrices.
In many countries, sewage sludge is spread on agricultural and other land. Hale et al. found high concentrations of PBDEs in "biosolids" from different regions of the United States, which suggests that the application of biosolids to soil may have some environmental consequences (Hale et al., 2001). A wastewater treatment plant in Palo Alto, California, was investigated to track PBDE release into the San Francisco Bay Estuary. The total concentrations of PBDEs ranged from 61 to $1440 \mathrm{ng} \mathrm{g}^{-1}$ dry weight and in the discharged effluent with the highest concentration reaching $29 \mathrm{ng} \mathrm{L}^{-1}$. Using mass balance loading estimation, it was estimated that $96 \%$ of the PBDEs that enter the wastewater treatment plant are adsorbed onto sludge assuming that there is no chemical, physical and biological degradations of the PBDEs, which may be a potential source of polybrominated dibenzo- $p$-dioxins (PBDDs) and furans (PBDFs) (North, 2004).

Sellström et al. (2005) studied the status of PBDEs in soils and earthworms that were collected from plots to which sewage sludge had been added. They found that the concentrations of PBDEs, including higher brominated BDEs-196, 197, 206, 207, and 209, increased with the dosage of sludge that was used. Thus, the atmospheric deposition cannot be the only source of PBDE found in soils, as the use of sewage sludge as a fertilizer can significantly increase PBDE concentrations.

Data on PBDEs in sewage sludge in East Asia are scarce. In our laboratory, PBDEs were recently determined in sewage sludge that was collected from 24 provinces of China. The $\Sigma_{12} \mathrm{PBDE}$ concentrations (excluding BDE-209) ranged from $6.2 \mathrm{ng} \mathrm{g}^{-1}$ to $50 \mathrm{ng} \mathrm{g}^{-1}$, dry weight, and BDE-209 concentrations ranged from non-detectable to $1108 \mathrm{ng} \mathrm{g}^{-1}$ (unpublished data, except for the figure for BDE-209). Composition analysis indicated that BDE-209 averaged 55\% of the total PBDEs contents. BDEs $-47,99$, and 183 are other major congeners.

Fig. 1 compares the PBDE concentrations in sludge from Germany, Sweden, the United States, and China. The PBDE levels in the sewage sludge collected in China were substantially lower than those in the sludge from Europe and North America.

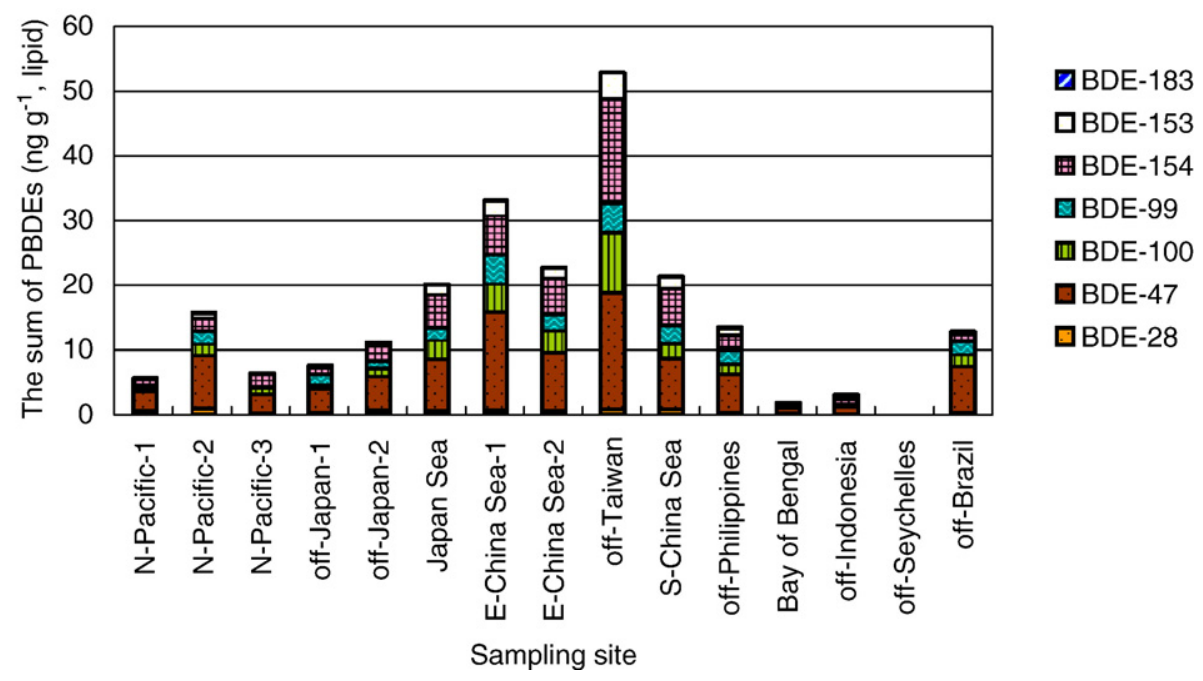

Fig. 2. PBDE concentrations (ng g PBDE concentrations (ng g ${ }^{-1}$, lipid) in the muscle of skipjack tuna collected from Asian offshore waters, off-Seychelles, off-Brazil, and in open Sea (Ueno et al., 2004). N-Pacific: North Pacific; E-China Sea: East China Sea; S-China Sea: South China Sea. 


\section{PBDEs distribution in biological samples}

Aquatic organisms are good bio-indicators of environmental pollution because they concentrate bioaccumulative pollutants in their bodies from water, and sediment, in additional to uptake from diet. Ueno et al. (2004) investigated PBDE concentrations in the muscle of skipjack tuna (Katsuwonus pelamis) from offshore waters in various regions in the world, and found that total PBDE concentrations ranged from $<0.1$ to $53 \mathrm{ng} \mathrm{g}^{-1}$ (lipid weight). Residual levels of PBDEs in the samples from East Asia were higher than those from other regions (Fig. 2), possibly because massive amounts of waste electric products have been manufactured in and imported this area. For example, in southeast China, there are many industrial manufacturers for computers, television, and other electronic and electrical equipment and appliances. Substantial amounts of PBDEs may be released into the environment and accumulated by skipjack tuna in this area. Among the PBDEs investigated, although there were high occurrences of the higher brominated compounds, the concentrations of less brominated congeners were generally higher.

The presence of PBDEs was reported in archived northern fur seal samples from the Pacific coast of Japan between 1972 and 1998 (Kajiwara et al., 2004). A total of eight congeners of di- to hepta-BDEs were detected in all the samples, with concentrations ranging from 0.33 to $100 \mathrm{ng} \mathrm{g}^{-1}$ lipid weight in 1972 and 1994, with average concentration increasing about 150-fold from 1972 to 1994 . However, the levels decreased by about $50 \%$ in 1998 which coincided with the withdrawal of penta-BDEs from use in Japan. The residual levels of these congeners were found to be higher than those in the Canadian Arctic (Ikonomou et al., 2002), but much lower than those in San Francisco (She et al., 2002) and Europe (Kalantzi et al., 2005; Hall et al., 2003). It was also found that the percentage of higher brominated congeners had increased since 1972, whereas the percentage of some lower brominated congeners had decreased, which fits with the increase in the use of higher brominated PBDEs between 1972 and 1998 (Kajiwara et al., 2004).

Ramu et al. (2005) measured the levels, profiles, and distribution of PBDEs in small cetaceans from Hong Kong waters. They analyzed ten targeted PBDE congeners in the blubber, liver and kidney of Indo-Pacific humpback dolphins (Sousa chinensis) and finless porpoises (Neophocaena phocaenoides) that were stranded in Hong Kong coastal waters between 1995 and 2001. The total concentrations of PBDEs ranged from 230 to $980 \mathrm{ng} \mathrm{g}^{-1}$ lipid weight in the blubber of finless porpoises and from 280 to $6000 \mathrm{ng} \mathrm{g}^{-1}$ lipid weight in the blubber of humpback dolphins. Recently, the geographical distribution of PBDEs in small cetaceans from Asian waters was reported based on samples collected from 1990 to 2001 and archived in the Environmental Specimen Bank for Global Monitoring (es-BANK) (Kajiwara et al., 2006a). The PBDE concentrations ranged from 6.0 to $6000 \mathrm{ng} \mathrm{g}^{-1}$ lipid weight (Table 3). On the whole, the residue levels in this study are comparable to those in various North American studies, but somewhat lower than the levels that have been reported in Europe. A plausible reason for this is the presence of untreated sewage into coastal waters in Hong Kong (Chan and Yung, 1995) and the export of waste electric products to developing Asian countries. BDE-3 and BDE-209 were not found among the congeners analyzed in the study, and BDEs47, 99, and 100 were predominant. The authors of the study suggested PBDEs should be classified as a priority pollutant in Asia.

Table 4 lists PBDE concentrations in other biological samples from Asia, such as birds and fish. The eggs of cormorants from Japan exhibited a higher level of PBDEs than the eggs of the guillemots but relatively lower levels than in gull eggs from other locations (Hites, 2004). The $\Sigma$ PBDE in fish that were collected in Japan and Turkey showed low concentrations of PBDEs, implying that the amount of PBDEs that would be ingested by animals from these food sources was unlikely to be significant.

Table 3

PBDE concentrations and congener distributions in dolphins (ng $\mathrm{g}^{-1}$, lipid)

\begin{tabular}{|c|c|c|c|c|c|}
\hline Location & Type & Date & Concentration & PBDE congener & References \\
\hline Hong Kong & Small cetaceans & $1995-2001$ & $230-6000$ & Ten target congener & Ramu et al. (2005) \\
\hline India & Dolphins & & $0.71-18$ & $28,47,99,100,153,154,183$ & Kannan et al. (2005) \\
\hline Japan & Porpoises & $1998-2000$ & $402(24-1300)$ & $3,15,28,47,99,100,153,154,183,209$ & Kajiwara et al. (2006a) \\
\hline Japan & Whales & $2000-2001$ & $425(300-650)$ & $3,15,28,47,99,100,153,154,183,209$ & Kajiwara et al. (2006b) \\
\hline Japan & Dolphins & 1999 & $320(300-340)$ & $3,15,28,47,99,100,153,154,183,209$ & Kajiwara et al. (2006a) \\
\hline Hong Kong, China & Porpoises & $2000-2001$ & $600(230-980)$ & $3,15,28,47,99,100,153,154,183,209$ & Kajiwara et al. (2006a) \\
\hline Hong Kong, China & Dolphins & $1997-2001$ & $1900(280-6000)$ & $3,15,28,47,99,100,153,154,183,209$ & Kajiwara et al. (2006a) \\
\hline India & Dolphins & $1990-1992$ & $8.9(6-12)$ & $3,15,28,47,99,100,153,154,183,209$ & Kajiwara et al. (2006a) \\
\hline Philippines & Dolphins & 1996 & $36(20-64)$ & $3,15,28,47,99,100,153,154,183,209$ & Kajiwara et al. (2006a) \\
\hline South China Sea & Finless porpoises & 1990 & $71-92$ & $3,15,28,47,99,100,153,154,183,209$ & Ramu et al. (2006) \\
\hline South China Sea & Finless porpoises & $2000-2001$ & $230-980$ & $3,15,28,47,99,100,153,154,183,209$ & Ramu et al. (2006) \\
\hline Japan & Whale & 2005 & $170-540$ & $28,47,99,100,153,154,183,209$ & Kajiwara et al. (2006b) \\
\hline U.K. & Porpoise blubber & 1996 & 1170 & $47,99,100,153,154$ & Law et al. (2002) \\
\hline U.K. & Porpoise blubber & 1997 & 1670 & $47,99,100,153,154$ & Law et al. (2002) \\
\hline U.K. & Porpoise blubber & 1998 & 1670 & $47,99,100,153,154$ & Law et al. (2002) \\
\hline North Atlantic & Dolphins & 1997 & $510-2410$ & $47,99,100,153,154$ & Tuerk et al. (2005) \\
\hline German North and Baltic Sea & Harbor porpoises & & 138 (median value) & $47,99,100,153,154$ & Beineke et al. (2005) \\
\hline
\end{tabular}


Table 4

PBDEs in other biosamples from Asia in $\mathrm{ng} \mathrm{g}^{-1}$; lipid weight

\begin{tabular}{|c|c|c|c|c|c|}
\hline Location & Type & Date & Concentration & PBDE congener & References \\
\hline $\begin{array}{l}\text { Mangrove habitats, } \\
\text { Singapore }\end{array}$ & $\begin{array}{l}\text { Biota species, including worms, } \\
\text { mussels, shells, etc. }\end{array}$ & 2004 & $27-860$ & $47,99,153$, and 154 & $\begin{array}{l}\text { Bayen et al. } \\
(2005)\end{array}$ \\
\hline \multirow[t]{3}{*}{ Japan } & Livers of cormorants & 2000 & $330-2600$ & Di- to De-BDE & $\begin{array}{l}\text { Watanabe et al. } \\
(2004)\end{array}$ \\
\hline & Eggs of cormorants & 2000 & $600-3300$ & & \\
\hline & Gizzards of shad & 2000 & $280-440$ & & \\
\hline Turkey & Fish (4 species) & 2003 & $\begin{array}{l}\text { ND-0.38 } \\
\text { (wet weight) }\end{array}$ & $28,47,99,100,153,154$ & $\begin{array}{l}\text { Erdogrul et al. } \\
(2005)\end{array}$ \\
\hline \multirow[t]{2}{*}{ Japan } & Dried sardines & 2001 & 0.4 (mean) & $\begin{array}{l}49,71,47,66,77,100,119,99,85, \\
126,154,153,138,183\end{array}$ & $\begin{array}{l}\text { Ashizuka et al. } \\
(2005)\end{array}$ \\
\hline & Raw fish and shellfish & 2001-2004 & ND-1.2 & $\begin{array}{l}49,71,47,66,77,100,119,99,85 \\
126,154,153,138,183\end{array}$ & $\begin{array}{l}\text { Ashizuka et al. } \\
(2005)\end{array}$ \\
\hline
\end{tabular}

In our lab, BDEs-47, 99, and 100 were detected in the muscle of carp that were collected from Namucuo Lake in Tibet with concentrations of $38 \mathrm{pg} \mathrm{g}^{-1}, 54 \mathrm{pg} \mathrm{g}^{-1}$, and $20 \mathrm{pg} \mathrm{g}^{-1}$ (wet weight; unpublished data), respectively. Namucuo Lake is the highest lake in the world (at attitude of $4718 \mathrm{~m}$ ) and is remote from any industrial or urban setting. PBDEs that are detected in the carp may be the result of long-range atmospheric transport and deposition into the lake water; or perhaps importation by transient wildlife, but the exact reason remains to be studied.

\section{PBDEs in human samples}

PBDEs make their way into the human body primarily through food intake, and ingestion of dust through inhalation (Harrad et al., 2004). Dermal uptake of BDE-47 has been demonstrated in rats and it may be a potential exposure pathway to humans (Staskal et al., 2005). Fatty fish from contaminated areas is a major source for humans. Breast's milk is a source for nursing children (Meironyté et al., 1999), with reports showing that individual maternal PBDE blood levels can predict fetal exposure. Large amounts of human samples, including tissue, blood (usually serum) and milk, from North America and Europe have been analyzed for PBDEs. A study in South Korea in 2001 collected blood samples from workers at municipal waste incinerators and the general population (Kim et al., 2005). The total concentrations of PBDE $(28,47,99,100,153,154$ and 183 ) in the blood samples of the workers ranged from 8.61 to $46.05 \mathrm{ng} \mathrm{g}^{-1}$ lipid weight, with an average value of $19.33 \mathrm{ng}$ $\mathrm{g}^{-1}$ lipid weight, and were slightly higher than the levels in the general population (7.24-28.90, mean $=15.24 \mathrm{ng} \mathrm{g}^{-1}$ lipid weight). The PBDE levels in blood of workers at municipal waste incinerators and the general population in South Korea are much higher than those that have been reported in European countries (11) (Fig. 3), but are lower than those reported in the United States in 2001 (Mazdai et al., 2003). BDE-47 was the predominant compound in the Korean study, and comprised $33 \%$ (mean) of the total concentration. It was also found that the level of BDE-183 in the blood of the workers was significantly higher than that in the general population. This may be due to the presence of octa-BDE in the waste that the workers handled. The time trends of PBDE levels in human blood in Japan and
Norway is shown in Fig. 3, from which it can be seen that the concentration of PBDEs in human blood has increased rapidly in recent years. High levels of deca-BDE (up to $13 \mathrm{ng} \mathrm{g}^{-1}$, lipid weight) were determined in Japanese human blood collected in 2004 (Takasuga et al., 2001), which contrasts with the previous reports that found BDEs-47, 99, and 153 to be prevalent. Possible sources for the more recent prevalence of deca-BDE are food and computer rich environments, such as offices and game rooms (de Boer et al., 1999).

A comparison of PBDE levels in human adipose in East Asia and Europe is given in Fig. 4. It can be seen that the most predominant congeners are BDEs-47 and 153, and BDE-209 is rarely analysed in human adipose tissue. Only BDEs-47 and 100 were detected in maternal adipose tissue from inhabitants of Singapore, but concentrations of BDEs-99, 153, and 154 were lower than limit of detection. On the whole, the levels of PBDEs in human adipose tissue in East Asia are relatively lower than those in Europe.

In another study, six congeners (BDEs-28, 47, 99, 100, 153, and 154) were measured in human breast milk that was collected from 13 regions of Japan in 2004 (Eslami et al., 2006).

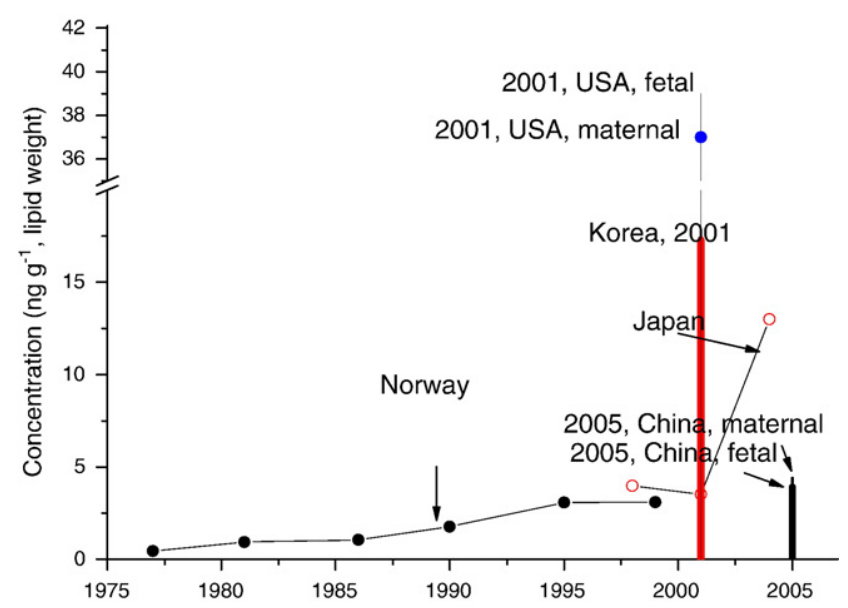

Fig. 3. PBDE levels in human blood by year in different countries (data from Kim et al., 2005; Mazdai et al., 2003; Takasuga et al., 2001; Thomsen et al., 2002; Bi et al., 2006). 


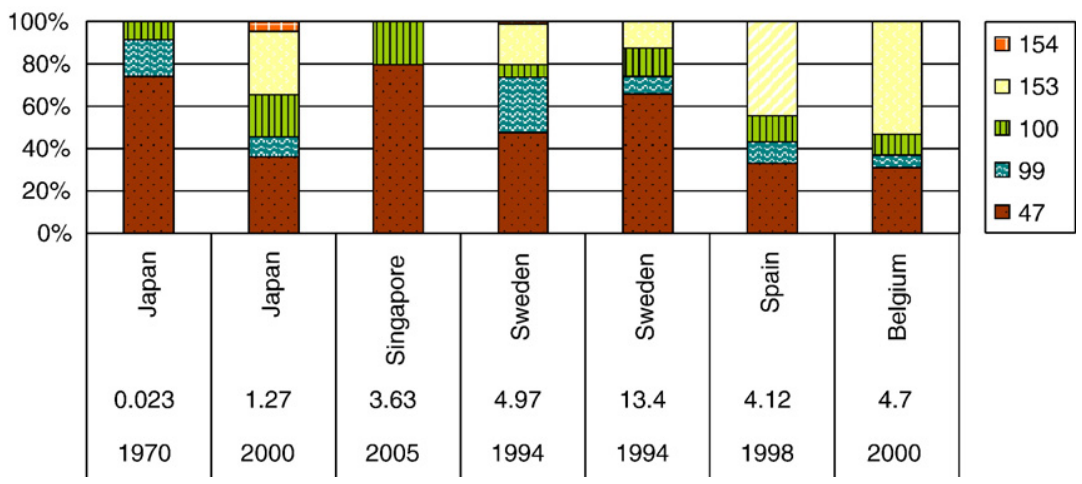

Fig. 4. Congener distributions in human adipose tissue from different countries (ng g ${ }^{-1}$; lipid weight) (Choi et al., 2003; Li et al., 2005). The upper number is the total concentration of PBDEs and the lower number represents the sampling date.

Compared to the data from 1978, PBDE concentrations had increased about ten fold (Fig. 5). BDE-47 was still the most predominant congener (59\% of the total concentrations), but in contrast to the finding in human blood samples, the concentration of BDE-99 was higher than that of BDE-153 in human breast milk. There appears to be no correlation between age and the total PBDE level in the study, which differs from the results of previous work (Hites, 2004).

\section{Temporal trends and the status of PBDEs in East Asia}

Temporal trend studies in East Asia indicate a sharp increase in PBDE concentrations in the environment and humans, which parallels the rapidly increasing market demand. Concentrations of PBDEs in sediment cores from Osaka Bay in Japan showed an increasing trend between 1960 and 2000 (Sakai et al., 2002). Inventories of PBDE sources in East Asia have not been made because of a lack of emission regulations. In addition to the sources similar to those in developed countries, such as PBDE manufacturing and applications, imported e-waste has become an important source of the PBDEs in China and other developing countries in East Asia. China is now preparing legislation on electronic waste and Japan has already enacted a law to decrease the amounts of PBDEs that are emitted into the environment.

On the whole, the concentrations of PBDEs in human and biological samples of East Asia is comparable to or lower than those in Europe, and, not surprisingly, are lower than those in North America. Asian market demand of deca-BDE accounts for about half of the world market, but the production and import of penta-BDEs are negligible, especially after the mid 1990s. In contrast, North America has consumed $98 \%$ of total penta-BDEs, and its production ceased since 2005. These differences may explain the lower accumulation of PBDEs in the human and biota populations of Asia than in North America, because penta-BDEs are highly bioaccumulative while decaBDE may not be. Another reason is perhaps the indoor contamination such as house dust. The dominant congener of PBDEs in house dust in Kuwait is BDE-209, which constituted $85 \%$ of the $\sum$ PBDEs (Gevao et al., 2006a), while in North America such as United States and Canada, tetra- and penta-
BDEs were frequently detected (Stapleton et al., 2005; Wilford et al., 2005). Difference in diets may also contribute to the difference in the levels of PBDEs in human (Harrad et al., 2004).

In the atmosphere, Asia also has PBDE concentrations generally comparable with or lower than those in developed countries. Reasons are not clear but may be also related to the low usage of PBDEs, penta-BDEs in particular in Asia. Congeners in penta-BDEs are about $10^{5}$ times more volatile than deca-BDE, based on the vapor pressure of BDE-47 and BDE-209. More monitoring data are needed to confirm this comparison and explain the differences.

Among all matrices, the most drastic difference among continents in PBDE levels is from sewage sludge produced during wastewater treatment. In most Chinese cities, the levels of PBDEs in sludge are much lower than those in the United States. The possible reason may be that wastewater discharged from industries is more strictly regulated and controlled in developed countries than in China where numerous local private and "collectively owned" factories and businesses may directly dump their wastes into natural waters in order to avoid treatment cost. The relatively low PBDE levels in sludge from Chinese wastewater treatment plants may not be indicative of levels of PBDE discharge and pollution.

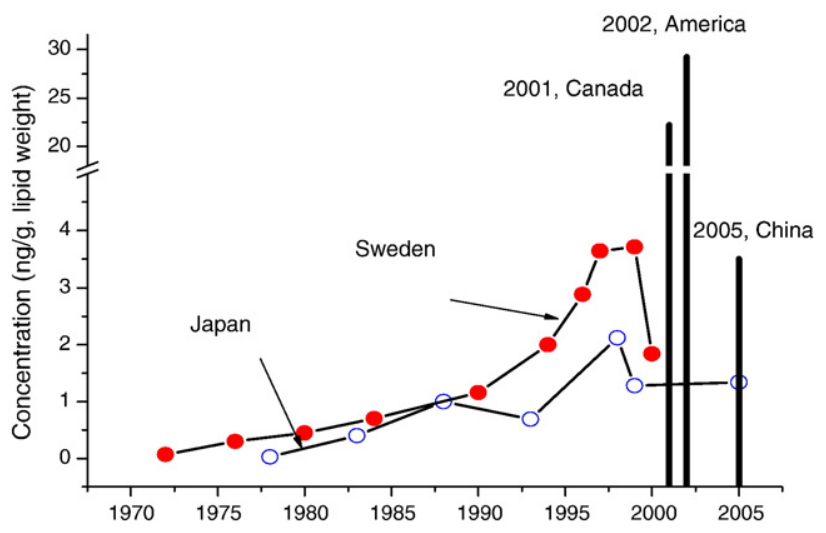

Fig. 5. PBDE concentrations in human milk by year in different countries (data from Hites, 2004; Bi et al., 2006; Eslami et al., 2006). 
In contrast, inter-continental comparison of sediment data does not seem to support that PBDE pollution is less severe in Asia. However, most sediment data in Asia were obtained using samples collected from densely populated and heavily industrialized "hot spots", such as the Pearl River Delta in Guangdong province of southern China. Considering the intense electronic/electrical industries plus the tremendous amount of imported e-wastes in this area, it is not surprising to see unusually high levels of PBDEs in the sediments of local water bodies.

More effort is needed to understand the magnitude and significance of long range PBDE transport across countries and continents. Lower brominated congeners tend to have higher long-range transport potential (Wania and Dugani, 2003) and are thus more widely dispersed. Their detection in the fish from a pristine lake of Qinghai-Tibet Plateau indicates such transport. Another important issue that we are unable to discuss in this paper is the potentially substantial in-situ degradation of deca-BDE and the consequential formation of highly toxic lower brominated congeners, or even PBDD/Fs, in the Asian environment over time. If this is indeed happening, several public health problems may emerge and/or aggravated in the future, because the emission of PBDEs to the environment will be unavoidable with the continuing production and use of decaBDE.

\section{Acknowledgements}

This work was jointly supported by the National Basic Research Program of China (2003CB415001), and the National Natural Science Foundation of China (20537020, 40590392). PKSL was funded by the Hong Kong Research Grants Council (CityU 1401/05M).

\section{Reference}

Agrell C, ter Schure AFH, Sveder J, Bokenstrand A, Larsson P, Zegers BN. Polybrominated diphenyl ethers (PBDES) at a solid waste incineration plant I: atmospheric concentrations. Atmos Environ 2004;38:5139-48.

Ashizuka Y, Nakagawa R, Tobiishi K, Hori T, Iida T. Determination of polybrominated diphenyl ethers and polybrominated dibenzo- $p$-dioxins/ dibenzofurans in marine products. J Agric Food Chem 2005;53:3807-13.

Bayen S, Wurl O, Karuppiah S, Sivasothi N, Lee HK, Obbard JP. Persistent organic pollutants in mangrove food webs in Singapore. Chemosphere 2005;61:303-13.

Beineke A, Siebert U, McLachlan M, Bruhn R, Thron K, Failing K, et al. Investigations of the potential influence of environmental contaminants on the thymus and spleen of harbor porpoises (phocoena phocoena). Environ Sci Technol 2005;39:3933-8.

Bi XH, Qu WY, Sheng GY, Zhang WB, Mai BX, Chen DJ, et al. Polybrominated diphenyl ethers in South China maternal and fetal blood and breast milk. Environ Pollut 2006;144:1024-30.

Bromine Science and Environmental Forum Total Market Demand; 2006. available at www.bsefcom.

Chan KK, Yung YK. Marine Water Quality in Hong Kong for 1994. Hong Kong Government Printer; 1995.

Chen SJ, Zeng EY, Luo XJ, Yu M, Sheng GY, Fu JM. Polybrominated diphenyl ethers (PBDEs) in surficial sediments of the Pearl River delta and adjacent South China Sea. Acta Sci Circumstantiae 2005;25:1265-71 (in Chinese).

Chen LG, Mai BX, Bi XH, Chen SJ, Wang XM, Ran Y, et al. Concentration levels, compositional profiles, and gas-particle partitioning of polybromi- nated diphenyl ethers in the atmosphere of an urban city in South China. Environ Sci Technol 2006a;40:1190-6.

Chen SJ, Gao XJ, Mai BX, Chen ZM, Luo XJ, Sheng GY, et al. Polybrominated diphenyl ethers in surface sediments of the Yangtze River Delta: levels, distribution and potential hydrodynamic influence. Environ Pollut 2006b;144:951-7.

Choi J-W, Fujimaki S, Kitamura K, Hashimoto S, Ito H, Suzuki N, et al. Polybrominated dibenzo- $p$-dioxins, dibenzofurans, and diphenyl ethers in Japanese human adipose tissue. Environ Sci Technol 2003;37:817-21.

Covaci A, Voorspoels S, de Boer J. Determination of brominated flame retardants, with emphasis on polybrominated diphenyl ethers (PBDEs) in environmental and human samples - a review. Environ Int 2003;29: $735-56$

Danish Environmental Protection Agency. Brominated flame retardants: substance flow analysis and assessment of alternatives; 1999.

Darnerud PO, Eriksen GS, Johannesson T, Larsen PB, Viluksela M. Polybrominated diphenyl ethers: occurrence, dietary exposure, and toxicology. Environ Health Perspect 2001;109:49-68.

de Boer J, deBoer K, Boon JP. In: Paasivirta J, editor. Polybrominated biphenyls and diphenyl ethers in the handbook of environmental chemistry. New York: Springer Verlag; 1999.

de Wit CA. An overview of brominated flame retardants in the environment. Chemosphere 2002;46:583-624.

Eljarrat E, Cal ADL, Larrazabal D, Fabrellas B, Fernandze-Alba ARF, Borrull F, et al. Occurrence of polybrominated diphenyl ethers, polychlorinated dibenzo-p-dioxins, dibenzofurans and biphenyls in coastal sediments from Spain. Environ Pollut 2005;136:493-501.

Environmental Agency Japan. Chemicals in the environment Report on environmental survey and wildlife monitoring of chemicals in FY 1988 and 1989 Environmental Agency Japan. Tokyo, Japan: Department of Environmental Health, Office of Health Studies; 1991.

Erdogrul Ö, Covaci A, Schepens P. Levels of organochlorine pesticides, polychlorinated biphenyls and polybrominated diphenyl ethers in fish species from Kahramanmaras, Turkey. Environ Int 2005;31:703-11.

Eriksson P, Jakobsson E, Fredriksson A. Brominated flame retardants: a novel class of developmental neurotoxicants in our environment? Environ Health Perspect 2001;109:903-8.

Eriksson J, Green N, Marsh G, Bergman A. Photochemical decomposition of 15 polybrominated diphenyl ether congeners in methanol/water. Environ Sci Technol 2004;38:3119-25.

Eslami B, Koizumi A, Ohta S, Inoue K, Aozasa O, Harada K, et al. Largescale evaluation of the current level of polybrominated diphenyl ethers (PBDEs) in breast milk from 13 regions of Japan. Chemosphere 2006;63:554-61.

Gevao B, Al-Bahloul M, Al-Ghadban N, Al-Omair A, Ali L, Zafar J, et al. House dust as a source of human exposure to polybrominated diphenyl ethers in Kuwait. Chemosphere 2006a;64:603-8.

Gevao B, Beg MU, Al-Ghadban AN, Al-Omair A, Helaleh M, Zafar J. Spatial distribution of polybrominated diphenyl ethers in coastal marine sediments receiving industrial and municipal effluents in Kuwait. Chemosphere 2006b;62:1078-86.

Gouin T, Thomas GO, Cousins I, Barber J, MacKay D, Jones KC. Air-surface exchange of polybrominated diphenyl ethers and polychlorinated biphenyls. Environ Sci Technol 2002;36:1426-34.

Gouin T, Thomas GO, Chaemfa C, Harner T, Mackay D, Jones KC. Concentrations of decabromodiphenyl ether in air from Southern Ontario: implications for particle-bound transport. Chemosphere 2006;64:256-61.

Hale RC, LaGuardia MJ, Harvey E, Gaylor MO, Duff WH. Flame retardants: persistent pollutants in land-applied sludges. Nature 2001;412:141-2.

Hale RC, Guardia MJ, Harvey E, Mainor TM. Potential role of fire retardanttreated polyurethane foam as a source of brominated diphenyl ethers to the US environment. Chemosphere 2002;46:729-35.

Hale RC, Alaee M, Manchester-Neesvig JB, Stapleton HM, Ikonomou MG. Polybrominated diphenyl ether flame retardants in the North American environment. Environ Int 2003;29:771-9.

Hall AJ, Kalantzi OI, Thomas GO. Polybrominated diphenyl ethers (PBDEs) in grey seals during their first year of life-are they thyroid hormone endocrine disrupters? Environ Pollut 2003;126:29-37. 
Harrad S, Wijesekera R, Hunter S, Halliwell C, Baker R. Preliminary assessment of UK human dietary and inhalation exposure to polybrominated diphenyl ethers. Environ Sci Technol 2004;38:2345-50.

Hayakawa K, Takatsuki H, Watanabe I, Sakai S. Polybrominated diphenyl ethers (PBDEs), polybrominated dibenzo- $p$-dioxins/dibenzofurans (PBDD/ Fs) and monobromo-polychlorinated dibenzo- $p$-dioxins/dibenzofurans (MoBPXDD/Fs) in the atmosphere and bulk deposition in Kyoto, Japan. Chemosphere 2004;57:343-56.

Hites RA. Polybrominated diphenyl ethers in the environment and in people: a meta-analysis of concentrations. Environ Sci Technol 2004;38:945-56.

Hoh E, Hites RA. Brominated flame retardants in the atmosphere of the EastCentral United States. Environ Sci Technol 2005;39:7794-802.

Ikonomou MG, Rayne S, Addison RF. Exponential increases of the brominated flame retardants, polybrominated diphenyl ethers, in the Canadian Arctic from 1981 to 2000. Environ Sci Technol 2002;36:1886-92.

Jaward FM, Farrar NJ, Harner T, Sweetman AJ, Jones KC. Passive air sampling of PCBs, PBDEs, and organochlorine pesticides across Europe. Environ Sci Technol 2004;38:34-41.

Jaward FM, Zhang G, Nam JJ, Sweetman AJ, Obbard JP, Kobara Y, et al. Passive air sampling of polychlorinated biphenyls, organochlorine compounds, and polybrominated diphenyl ethers across Asia. Environ Sci Technol 2005;39:8638-45.

Kajiwara N, Ueno D, Takahashi A, Baba N, Tanabe S. Polybrominated diphenyl ethers and organochlorines in archived northern fur seal samples from the Pacific coast of Japan, 1972-1998. Environ Sci Technol 2004;38:3804-9.

Kajiwara N, Kamikawa S, Ramu K, Ueno D, Yamada TK, Subramanian A, et al. Geographical distribution of polybrominated diphenyl ethers (PBDEs) and organochlorines in small cetaceans from Asian waters. Chemosphere 2006a;64:287-95.

Kajiwara N, Kunisue T, Kamikawa S, Ochi Y, Yano S, Tanabe S. Organohalogen and organotin compounds in killer whales mass-stranded in the Shiretoko Peninsula, Hokkaido, Japan. Mar Pollut Bull 2006b;52:1066-76.

Kalantzi OI, Hall AJ, Thomas GO, Jones KC. Polybrominated diphenyl ethers and selected organochlorine chemicals in grey seals (Halichoerus grypus) in the North Sea. Chemosphere 2005;58:345-54.

Kannan K, Ramu K, Kajiwara N, Sinha R, Tanabe KS. Organochlorine pesticides, polychlorinated biphenyls, and polybrominated diphenyl ethers in Irrawaddy dolphins from India. Arch Environ Contam Toxicol 2005;49:415-20.

Kim BH, Ikonomou MG, Lee SJ, Kim HS, Chang YS. Concentrations of polybrominated diphenyl ethers, polychlorinated dibenzo- $p$-dioxins and dibenzofurans, and polychlorinated biphenyls in human blood samples from Korea. Sci Total Environ 2005;336:45-56.

Knoth W, Mann W, Meyer R, Nebhuth J. Occurrence and fate of PBDE in sewage sludge from municipal wastewater treatment plants. Organohalog Compd 2004;66:3749-54.

Korea Environment Institute (KEI). Environmental risk assessment and regulation on flame retardants. Seoul, Korea: Korea Environment Institute; 2001 (in Korean).

Korea Institute of Science and Technology Information (KISTI). Flame retardants. Seoul, Korea: Korea Institute of Science and Technology Information; 2002 (in Korean).

Law RJ, Allchin CR, Bennett ME, Morris S, Rogan E. Polybrominated diphenyl ethers in two species of marine top predators from England and Wales. Chemosphere 2002;46:673-81.

Law RJ, Alaee M, Allchin CR, Boon JP, Lebeuf M, Lepom P, et al. Levels and trends of polybrominated diphenyl ethers and other brominated flame retardants in wildlife. Environ Int 2003;29:757-70.

Law RJ, Allchin CR, de Boer J, Covaci A, Herzke D, Lepom P, et al. Levels and trends of brominated flame retardants in the European environment. Chemosphere 2006;64:187-208.

Lee RGM, Thomas GO, Jones KC. PBDEs in the atmosphere of three locations in Western Europe. Environ Sci Technol 2004;38:699-706.

Li QQ, Loganath A, Chong YS, Obbard JP. Determination and occurrence of polybrominated diphenyl ethers in maternal adipose tissue from inhabitants of Singapore. J Chromatogr B 2005;819:253-7.

Liu HX, Zhang QH, Jiang GB, Cai ZW. Polybrominated diphenyl ethers and its related environmental problems. Prog Chem 2005a;17:554-62 (in Chinese).
Liu Y, Zheng GJ, Yu HX, Martin M, Richardson BJ, Lam MHW, et al. Polybrominated diphenyl ethers (PBDEs) in sediments and mussel tissues from Hong Kong marine waters. Mar Pollut Bull 2005b;50:1173-84.

Mai BX, Chen SJ, Luo XJ, Chen LG, Yang QS, Sheng GY, et al. Distribution of polybrominated diphenyl ethers in sediments of the Pearl River Delta and adjacent South China Sea. Environ Sci Technol 2005;39:3521-7.

Martin M, Lam PSK, Richardson BJ. An Asian quandary: where have all of the PBDEs gone? Mar Pollut Bull 2004;49:375-82.

Mazdai A, Dodder NG, Abernathy MP, Hites RA, Bigsby RM. Polybrominated diphenyl ethers in maternal and fetal blood samples. Environ Health Perspect 2003;111:1249-52.

Meironyté D, Norén K, Bergman A. Analysis of polybrominated diphenyl ethers in Swedish human milk A time-related trend study, 1972-1997. J Toxicol Environ Health 1999;58:329-41.

Moon H, Chio H, Kim S, Jeong S, Lee P, Ok G. Contaminations of polybrominated diphenyl ethers in marine sediments from the southeastern coastal areas of Korea. Organohalog Compd 2002;58:217-20.

Moon HB, Kannan K, Lee SJ, Choi M. Polybrominated diphenyl ethers (PBDEs) in sediment and bivalves from Korean coastal waters. Chemosphere 2006;66:243-51.

Norén K, Meironyté D. Certain organochlorine and organobromine contaminants in Swedish human milk in perspective of past 20-30 years. Chemosphere 2000;40:1111-23.

North KD. Tracking polybrominated diphenyl ether peleases in a wastewater treatment plant effluent, Palo Alto, California. Environ Sci Technol 2004;38:4484-8.

Öberg K, Warman K, Öberg T. Distribution and levels of brominated flame retardants in sewage sludge. Chemosphere, 2002;48:805-9.

Ohta S, Nakao T, Nishimura H, Okumura T, Aozasa O, Miyata H. Contamination levels of PBDEs, TBBPA, PCDDs/DFs, PBDDs/DFs and PXDDs/DFs in the environment of Japan. Organohalog Compd 2002;57:57-60.

Oros DR, Hoover D, Rodigari F, Crane D, Sericano J. Levels and distribution of polybrominated diphenyl ethers in water, surface sediments, and bivalves from the San Francisco estuary. Environ Sci Technol 2005;39:33-41.

Ramu K, Kajiwara N, Tanabe S, Lam PKS, Jefferson TA. Polybrominated diphenyl ethers (PBDEs) and organochlorines in small cetaceans from Hong Kong waters: levels, profiles and distribution. Mar Pollut Bull 2005;51:669-76.

Ramu K, Kajiwara N, Lam PKS, Jefferson TA, Zhou K, Tanabe ST. Temporal variation and biomagnification of organohalogen compounds in finless porpoises (Neophocaena phocaenoides) from the South China Sea. Environ Pollut 2006;144:516-23.

Sakai S, Hayakawa K, Okamoto K, Takatuki H. Time trends and horizontal distribution of polybrominated diphenyl ethers (PBDEs) in sediment cores from Osaka Bay, Japan. Organohalog Compd 2002;58:189-92.

Sellström U, de Wit CA, Lundgren N, Tysklind M. Effect of sewage-sludge application on concentrations of higher-brominated diphenyl ethers in soils and earthworms. Environ Sci Technol 2005;39:9064-70.

She J, Petreas M, Winkler J, Visita P, McKinney M, Kopec D. PBDEs in the San Francisco Bay Area: measurements in harbor seal blubber and human breast adipose tissue. Chemosphere 2002;46:697-707.

Söderström G, Sellstrom U, de Wit CA, Tysklind M. Photolytic debromination of decabromodiphenyl ether (BDE 209). Environ Sci Technol 2002;38:127-32.

Song WL, Ford JC, Li A, Mills WJ, Buckley DR, Rockne KL. Polybrominated diphenyl ethers in the sediments of the Great Lakes 1. Lake Superior. Environ Sci Technol 2004;38:3286-93.

Song WL, Li A, Ford JC, Sturchio NC, Rockne KJ, Buckley DR, et al. Polybrominated diphenyl ethers in the sediments of the Great Lakes. 2. Lakes Michigan and Huron. Environ Sci Technol 2005a;39:3474-9.

Song WL, Ford JC, Li A, Sturchio NC, Rockne KJ, Buckley DR, et al. Polybrominated diphenyl ethers in the sediments of the Great Lakes. 3. Lakes Ontario and Erie. Environ Sci Technol 2005b;39:5600-5.

Stapleton HM, Dodder NG, Offenberg JH, Schantz MM, Wise SA. Polybrominated diphenyl ethers in house dust and clothes dryer lint. Environ Sci Technol 2005;39:925-31.

Staskal DF, Diliberto JJ, DeVito MJ, Birnbaum LS. Toxicokinetics of BDE 47 in female mice: effect of dose, route of exposure, and time. Toxicol Sci 2005;83:215-23. 
Sun FH, Zhou QX. Research advance on environmental exposure and ecotoxicological effects of polybrominated diphenyl ethers (PBDEs). Chin J Appl Ecol 2005;16:379-84 (in Chinese).

Takasuga T, Senthilkumar K, Takemori H, Ohi E, Tsuji H, Nagayama J. Impact of fermented brown rice with Aspergillus oryzae (FEBRA) intake and concentrations of polybrominated diphenylethers (PBDEs) in blood of humans from Japan. Chemosphere 2001;57:795-811.

Tamade Y, Shibukawa S, Osaki H, Kashimoto S, Yagi Y, Sakai S, et al. A study of brominated compounds release from appliance recycling facility. Organohalog Compd 2002;56:189-92.

ter Schure AFH, Agrell C, Bokenstrand A, Sveder J, Larsson P, Zegers BN. Polybrominated diphenyl ethers at a solid waste incineration plant II: atmospheric deposition. Atmos Environ 2004a;38:5149-55.

ter Schure AFH, Larsson P, Agrell C, Boon JP. Atmospheric transport of polybrominated diphenyl ethers and polychlorinated biphenyls to the Baltic Sea. Environ Sci Technol 2004b;38:1282-7.

Thomsen C, Lundanes E, Becher G. Brominated flame retardants in archived Serum samples from Norway: a study on temporal trends and the role of age. Environ Sci Technol 2002;36:1414-8.

Tuerk KJS, Kucklick JR, Becker PR, Stapleton HM, Baker JE. Persistent organic pollutants in two dolphin species with focus on toxaphene and polybrominated diphenyl ethers. Environ Sci Technol 2005;39:692-8.

Ueno D, Kajiwara N, Tanaka H, Subramanian A, Fillmann G, Lam PKS, et al. Global pollution monitoring of polybrominated diphenyl ethers using skipjack tuna as a bioindicator. Environ Sci Technol 2004;38:2312-6.

Verslycke TA, Vethaak AD, Arijs K, Janssen CR. Flame retardants, surfactants and organotins in sediment and mysid shrimp of the Scheldt estuary (the Netherlands). Environ Pollut 2005;136:19-31.

Viberg H, Fredriksson A, Eriksson P. Neonatal exposure to the brominated flame retardant 2,2',4,4',5-pentabromodiphenyl ether causes altered susceptibility in the cholinergic transmitter system in the adult mouse. Toxicol Sci 2002;67:104-7.

Wang DL, Cai ZW, Jiang GB, Leung A, Wong MH, Wong WK. Determination of polybrominated diphenyl ethers in soil and sediment from an electronic waste recycling facility. Chemosphere 2005a;60:810-6.

Wang XM, Ding X, Mai BX, Xie ZQ, Xiang CH, Sun LG, et al. Polybrominated diphenyl ethers in airborne particulates collected during a research expedition from the Bohai Sea to the Arctic. Environ Sci Technol 2005b;39:7803-9.

Wang YW, Zhang QH, Lv JX, Li A, Liu HX, Li GG, et al. Polybrominated diphenyl ethers and organochlorine pesticides in sewage sludge of wastewater treatment plants in China. Chemosphere 2007;68:1683-91.

Wania F, Dugani CB. Assessing the long-range transport potential of polybrominated diphenyl ethers: a comparison of four multimedia models. Environ Toxicol Chem 2003;22:1252-61.

Watanabe I, Kawano M, Tatsukawa R. Polybrominated and mixed polybromo/ chlorinated dibenzo- $p$-dioxins and -dibenzofurans in the Japanese environment. Organohalog Compd 1995;24:337-40.

Watanabe K, Senthilkumar K, Masunaga S, Takasuga T, Iseki N, Morita M. Brominated organic contaminants in the liver and egg of the common cormorants (phalacrocorax carbo) from Japan. Environ Sci Technol 2004;38:4071-7.

WHO. Environmental health criteria 162: Brominated diphenyl ethers. Geneva: World Health Organisation; 1994. p. 31-4.

Wilford BH, Shoeib M, Harner T, Zhu J, Jones KC. Polybrominated diphenyl ethers in indoor dust in Ottawa, Canada: implications for sources and exposure. Environ Sci Technol 2005;39:7027-35.

Wurl O, Obbard JP. Organochlorine pesticides, polychlorinated biphenyls and polybrominated diphenyl ethers in Singapore's coastal marine sediments. Chemosphere 2005;58:925-33.

Wurl O, Potter JR, Durville C, Obbard P. Polybrominated diphenyl ethers (PBDEs) over the open Indian Ocean. Atmos Environ 2006;40:5558-65.

Xia J, Wang LJ, Luo HA. Present status and developing tendency of flame retardant. Appl Chem Ind 2005;34:1-4.

Yang YL, Pan J, Li Y, Yin XC, Shi L. PCNs and PBDEs in near-shore sediments of Qingdao. Chin Sci Bull 2003;48:2244-50.

Zheng GJ, Martin M, Richardson BJ, Yu HX, Liu Y, Zhou CH, et al. Concentrations of polybrominated diphenyl ethers (PBDEs) in Pearl River Delta sediments. Mar Pollut Bull 2004;49:520-4.

Zhou T, Taylor MM, DeVito MJ, Crofton KM. Developmental exposure to brominated diphenyl ethers results in thyroid hormone disruption. Toxicol Sci 2002;66:105-16. 